\title{
Erratum to: The Influence of God and Providence on Happiness and the Quality of Life of Patients Benefiting from Aesthetic Medicine Treatments in Poland
}

\author{
Anna Galęba ${ }^{1,2,3} \cdot$ Beata Bajurna ${ }^{1,3}$
}

Published online: 1 May 2015

(C) Springer Science+Business Media New York 2015

\section{Erratum to: J Relig Health DOI 10.1007/s10943-015-0036-3}

The original version of this article unfortunately contained an error in the author affiliation. The affiliations were submitted and published incorrectly. The correct affiliations are given in this erratum.

The online version of the original article can be found under doi:10.1007/s10943-015-0036-3.

Anna Galęba

dr.anna@annagaleba.pl

Beata Bajurna

beatabajurna@onet.eu

1 Department of Social Medicine, Karol Marcinkowski University of Medical Sciences, Poznan, Poland

2 Private Practice of Aesthetic Medicine and Anti-Aging, Warsaw, Poznan, Poland

3 Rokietnicka Str., 60-806 Poznan, Poland 